\title{
PENGEMBANGAN ALAT PERAGA KEAKSARAAN BERBASIS KEMAMPUAN SIMBOLIK PADA ANAK ANAK TK DI GUGUS 11 BUNGA MATAHARI PALANGKARAYA
}

\author{
Sophia Oktavia Balimulia ${ }^{1}$ \& Elisabeth Fransisca Saragi Sitio ${ }^{1}$ \\ ${ }^{1}$ Program Studi PG PAUD FKIP Universitas Palangka Raya \\ Jl. H. Timang Komplek Kampus Tunjung Nyaho Palangka Raya \\ Email : Sophia_oktavia@yahoo.com
}

\begin{abstract}
ABSTRAK
Anak usia TK adalah anak usia dini dengan rentang usia 4-6 tahun. Kemampuan kognitif anak usia dini menurut Piaget masuk pada tahapan pra operasional dan menuju ke tahapan operasional kongkret. Pada tahapan praoperasional ini anak masuk pada subtahap simbolik, yang artinya anak mampu mengembangkan kemampuan secara mental untuk membayang suatu objek yang tidak ada (Mutiah, 2010) atau seperti yang dikemukakan oleh Runtukahu (2014) bahwa ketika anak berada dalam tahap simbolik, anak akan mampu memanipulasi simbol atau lambang objek-objek tertentu. Berbasis kemampuan simbolik yang ada pada anak usia dini ini, peneliti mencoba mengembangkan alat peraga keaksaraan dengan produk lokal yang merupakan produk/benda khas yang ada di Kalimantan Tengah guna mempermudah anak mengingat simbol simbol angka yang merupakan lingkup perkembangan keaksaraan yang diajarkan pada anak berusia 4-6 tahun (anak usia TK). Pengembangan alat peraga keaksaraan ini akan berupa media visual yaitu kartu angka. Pengembangan alat peraga ini akan memanfaatkan proses asosiasi yang berkembang pada tahapan simbolik ini. Proses asosiasi merupakan proses dimana anak mulai menghubungkan pengetahuan yang sudah dimilikinya dengan pengetahuan baru yang didapatkannya atau yang ada disekitarnya. Piaget menyatakan bahwa anak akan membentuk schemata baru tanpa membuang yang sudah ada tetapi memperbaiki dan menguatkan yang sebelumnya dalam proses asosiasi ini. Oleh karena itu berdasarkan teori yang ada, peneliti berencana membuat alat peraga keaksaraan dalam bentuk kartu angka yang dilengkapi gambar asosiatif yang menyerupai bentuk angka yang terispirasi dari produk/benda khas lokal sehingga akan memudahkan anak usia dini belajar mengenal angka.

Metode penelitian ini akan menggunakan metode penelitian dan pengembangan (Research and Development), yaitu metode penelitian yang digunakan untuk menghasilkan produk tertentu dan menguji keefektifan produk tersebut. Langkah pengembangan yang direncanakan hanya sampai pada tahap ketujuh (revisi produk) dan Teknik pengumpulan data yang digunakan adalah lembar validasi, lembar observasi dan dokumentasi. Berdasarkan hasil penelitian ini diperoleh gambar gambar asosiatif yang
\end{abstract}


berasal dari produk dan benda yang menjadi kekhasan lokal Kalimantan

Tengah.

\section{Kata kunci : Alat peraga, Berfikir simbolik, Gambar asosiasi}

\section{PENDAHULUAN}

Aksara adalah sebuah sistem penulisan suatu bahasa dengan menggunakan tanda-tanda simbol, sebuah alfabet, huruf ( Hidayat 2009:19 ). Sedangkan UNESCO mendefinisikan kemampuan keaksaraan atau melek aksara sebagai kemampuan seseorang untuk membaca dan menulis kalimat sederhana yang diperlukan dalam kehidupan sehari-hari ( Bawani 2014).

Kemampuan keaksaraan ini juga telah diajarkan di Taman kanak-kanak, namun pada tingkat yang sangat dasar yaitu seperti mampu menyebut simbol huruf yang dikenal (a disebut huruf a, 1 disebut angka 1, dst), namun yang dilakukan sekolah dalam pengenalan simbol huruf atau angka ini tanpa disertai proses asosiasi didalamnya, sehingga hal ini seringkali menimbulkan kesulitan pada anak untuk mengingat simbol angka atau huruf yang diajarkan padanya. Apabila anak kesulitan dalam mengenal simbol huruf atau angka yang diajarkan padanya maka pada kemampuan aksara yang lain seperti menulis huruf-huruf dari namanya sendiri atau menyebutkan angka yang lambang bilangannya ditunjukan maka anak bisa dipastikan anak mengalami kesulitan pula.

Kemampuan guru dalam menyediakan alat peraga pembelajaran yang tepat akan sangat membantu anak mengingat simbol simbol huruf dan angka yang akan diajarkan padanya. Ketika anak berusia 2-7 tahun anak masuk pada tahap berfikir praoperasioanal menurut teori Piaget (Sriningsih, 2009). Pada tahap ini kemampuan anak berfikir simbolik berkembang dengan pesat. Pada perkembangan berpikir simbolik, yang terjadi adalah anak-anak mulai menggunakan simbol-simbol ketika mereka menggunakan sebuah objek atau tindakan untuk mempresentasikan sesuatu yang tidak ada dihadapannya. Tahap simbolik termasuk dalam tahap belajar mengenai konsep. Anak belajar mengenai simbol atau lambang dari objek-objek yang ada dipikiran dan yang ada dilingkungan sekitarnya. Konsep mengenai simbol-simbol yang ada dalam pikirannya kemudian diungkapkan melalui kata-kata ataupun kalimat (Mutiah, 2010). Berdasarkan kemampuan simbolik yang berkembang pada usia anak 2-7 tahun ini, 
maka dapat dimanfaatkan untuk mengajari anak mengenal simbol/lambang huruf maupun angka. Pengenalan angka di sekolah yang dilakukan oleh guru dapat terbantu dengan penggunaan alat peraga yang tepat yang memanfaatkan kemampuan simbolik yang berkembang pada masa usia dini ini.

Alat peraga yang telah banyak dijual di pasaran saat ini kebanyakan hanya berupa kartu angka. Kartu angka ini berdasarkan hasil observasi kurang memberikan hasil yang maksimal dalam membantu anak mengingat simbol angka ini, karena dalam kartu angka ini tidak terdapat gambar asosiasi yang dapat membantu anak melakukan peta kognitif dalam mengingat simbol angkanya.

Tujuan dan urgensi penelitian ini adalah untuk memberikan sumbangan terhadap perkembangan keilmuan, khususnya tentang pengembangan alat peraga bagi anak usia dini. Selain itu tujuan dari penelitian ini adalah mengembangkan alat peraga keaksaraan dengan menggunakan gambar asosiasi dengan memanfaatkan kemampuan simbolik yang berkembang pada anak usia dini. Penelitian ini penting dilakukan untuk memaksimalkan potensi anak dalam berfikir simbolik dengan dibantu alat peraga belajar yang tepat bagi anak. Pengembangan alat peraga keaksaraan ini akan dirancang dengan memasukan gambar asosiasi yang menyerupai bentuk angka sehingga akan memudahkan anak mengingat simbol angka yang diajarkan padanya dan dengan adanya pengembangan alat peraga keaksaraan ini akan memudahkan guru dan orang tua dalam mengajarkan angka pada anak usia dini.

Adapun uraian tentang spesifikasi khusus penelitian ini adalah peneliti akan melakukan penelitian dan pengumpulan data yang berkaitan produk atau benda kekhasan lokal yang ada di Kalimantan Tengah ini yang akan digunakan sebagai pilihan gambar asosiasi yang akan dihubungkan dengan simbol angka. Setelah itu peneliti akan melakukan perencanaan tentang bahan bahan apa saja yang akan digunakan untuk membuat produk alat peraga yang akan dikembangkan lalu kemudian melakukan pengembangan draf produk dan dilanjutkan dengan direncanakan uji coba lapangan terhadap alat peraga yang dihasilkan dan setela itu akan dilakukan revisi uji coba pertama dan setelah direvisi akan dilakukan uji coba kedua ke lapangan serta penyempurnaan produk alat peraga yang dikembangkan.Awalnya penelitian ini direncankan dilakukan pada TK yang masuk dalm Gugus Sawi Palangkaraya, namun 
pertanggal 14 Oktober 2019 terdapat perombakan nama Gugus dan dari yang awal bernama Gugus Sawi berubah nama menjadi Gugus 11 Bunga Matahari.

\begin{abstract}
Alat Peraga
Alat peraga adalah suatu alat yang digunakan pendidik untuk mempermudah peserta didik dalam memahami materi pembelajaran (Sulastri, Jamaludin, dan Hasdin dalam nabila, 2018). Peran alat peraga salah satunya adalah menjadikan konsep yang abstrak menjadi lebih kongkrit. Dimana para pendidik akan lebih mudah dalam penyampaian materinya kepada peserta didik. Pendidik juga selalu di tuntut untuk bisa memberikan pembelajaran yang menyenangkan tanpa membuat peserta didik bingung akan bahasan materi yang disampaikan.
\end{abstract}

\title{
Manfaat Alat Peraga
}

Manfaat alat peraga dalam pendidikan banyak sekali. Adapun manfaat yang dapat diperoleh dari penggunaan alat peraga ini menurut Annisah (dalam Nabila, 2018) adalah:

1.) Proses belajar mengajar termotivasi.

2.) Konsep materi yang disajikan dalam bentuk kongkrit, dapat di pahami dengan mudah dan jelas. 3.) Pembelajaran yang abstrak lebih mudah dipahami dengan alat peraga.

3.) Konsep abstrak dapat dipakai sebagai objek penelitian maupun sebagai alat untuk meneliti ide-ide, gagasan serta relasi yang lebih banyak lagi.

\section{Kriteria Alat Peraga}

Kelayakan alat peraga adalah pantas atau tidaknya alat peraga tersebut digunakan dalam pembelajaran fisika di kelas. Kelayakan alat peraga tersebut menurut Afriyanto (dalam Nabila, 2018) diantaranya yaitu :

1.) Alat peraga harus sesuai dengan kurikulum .

2.) Bentuk dan performa dari alat peraga harus menarik dan sesuai dengan subjek (peserta didik) yang hendak diteliti.

3.) Alat peraga mudah dipahami oleh peserta didik dan keterbacaan alat mudah. 
4.) Alat peraga hendaknya mudah digunakan.

Sedangkan Sastradiradja (dalam Mariyah, Aprinastuti \& Anggadewi, 2017) mengungkapkan bahwa penggunaan alat peraga dalam pembelajaran berfungsi untuk: 1) membantu murid belajar lebih banyak 2) membantu murid mengingat lebih lama 3) memperlengkapi rangsangan yang efektif untuk belajar 4) menjadikan belajar yang lebih kongkrit (nyata) 5) membawa dunia ke dalam kelas dan 6) memberikan pendekatan-pendekatan bayangan yang tajam dari satu subyek yang sama. Penggunaan alat peraga dalam pembelajaran dimaksudkan untuk mengoptimalkan keseluruhan fungsi panca indra anak (Widiyatmoko \& Pamela dalam Mariyah, Aprinastuti \& Anggadewi, 2017). Sundayana (dalam Mariyah, Aprinastuti \& Anggadewi, 2017) menyebutkan kriteria alat peraga yang baik diantaranya tahan lama, menarik, sederhana, sesuai dengan konsep materi, menjadi dasar tumbuhnya konsep abstrak bagi anak, serta menjadikan belajar menjadi aktif dan mandiri.

\section{Kemampuan Berpikir Simbolik}

Pada perkembangan berpikir simbolik, yang terjadi adalah anak-anak mulai menggunakan simbol-simbol ketika mereka menggunakan sebuah objek atau tindakan untuk mempresentasikan sesuatu yang tidak ada dihadapannya. Tahap simbolik termasuk dalam tahap belajar mengenai konsep. Anak belajar mengenai simbol atau lambang dari objek-objek yang ada dipikiran dan yang ada dilingkungan sekitarnya. Konsep mengenai simbol-simbol yang ada dalam pikirannya kemudian diungkapkan melalui kata-kata ataupun kalimat. Pengungkapan secara verbal yang terjadi dapat membuktikan bahwa anak mulai mengenal akan konsep-konsep yang ada. Mutiah (2010) menyatakan bahwa: Sub tahap fungsi simbolik ialah subtahap pertama pemikiran praoperasional. Pada subtahap ini, anak-anak mengembangkan kemampuan untuk membayangkan secara mental suatu objek yang tidak ada. Kemampuan untuk berpikir simbolik semacam itu disebut fungsi simbolik, dan kemampuan itu mengembangkan secara cepat dunia mental anak. Sedangkan Runtukahu, dkk (2014) "Dalam tahap simbolik, anak memanipulasi simbol atau lambang objek-objek tertentu. Siswa mampu menggunakan notasi tanpa tergantung pada objek nyata."

Berdasarkan pendapat yang diungkapkan beberapa ahli di atas yang dimaksud dengan perkembangan berpikir simbolik adalah suatu proses perubahan yang tersusun dalam jangka waktu tertentu yakni yang terjadi pada tahap praoperasional anak yakni 
pada usia 2-7 tahun. Pada tahap berpikir simbolik, anak sudah dapat mengungkapkan konsep yang ada dalam pikiran dan imajinasinya dan diungkapkan dalam bentuk katakata maupun kalimat. Berpikir simbolik merupakan kemampuan dalam mengenal lambang bilangan 1-10 serta lambang huruf vokal dan konsonan. Tahap simbolik termasuk dalam tahap belajar mengenai konsep. Hal tersebut membutuhkan kemampuan dalam merumuskan konsep yang dikemas dalam bentuk kata-kata maupun kalimat. Konsep dipelajari agar anak mengenal suatu objek namun tidak bergantung dengan objek nyata.

\section{Ciri-Ciri Berpikir Simbolik}

Berpikir simbolik dimana anak mulai bermain khayal dan bermain pura- pura. Dalam hal ini berpikir simbolik memiliki keterkaitan dalam mengembangkan kreativitas. Pada masa ini anak lebih banyak bertanya dan menjawab pertanyaan, mencoba berbagai hal berkaitan dengan konsep angka, ruang, kuantitas, dan sebagainya. Pada masa ini anak juga sudah mulai menggunakan berbagai benda sebagai simbol. Misalnya menganggap daun sebagai uang, kadang-kadang berbicara atau pura-pura memberi makan atau minum pada bonekanya. Kegiatan simbolik merupakan latihan berpikir dan mengarahkan anak untuk menyesuaikan diri terhadap lingkungannya, dan dalam Perkembangannya akan semakin mendekati kenyataan.

\section{Gambar Asosiatif}

Asosiasi ialah hubungan antara tanggapan yang satu dengan tanggapan yang lain dan saling mereproduksi. Dengan adanya asosiasi maka apabila tanggapan tersebut direproduksi maka akan menarik tanggapan lain yang berasosiasi sehingga tanggapan tersebut ikut masuk ke alam sadar. (dalam Fitriyanti, 2015). Walaupun dalam asosiasi ada semacam kebebasan, namun pada dasarnya mengikuti hukum-hukum tertentu, seperti yang dikemukakan oleh Aristoteles sebagai berikut:

a. Hukum I: Hukum sama waktu

Tanggapan-tanggapan yang muncul pada saat yang sama, akan terasosiasi dan direproduksi bersama dalam alam sadar. Misalnya, jika seseorang mengingat gurunya maka akan teringat pula cara mengajarnya.

b. Hukum II: Hukum berurutan 
Tanggapan-tanggapan yang mempunyai hubungan berturut-turut, berasosiasi dan direproduksikan ke dalam alam sadar. Misalnya, jika kita mengingat huruf a, maka akan ingat huruf b, c, d, e, dan sebagainya.

c. Hukum III: Hukum persamaan

Tanggapan-tanggapan yang hampir sama dan benda-benda yang hampir sama berasosiasi dan direproduksi ke dalam alam kesadaran. Misalnya, melihat potret teman akan mengingat orangnya, melihat lilin teringat angka 1.melihat bebek teringat angka 2.

d. Hukum IV: Hukum berlawanan

Tanggapan-tanggapan yang berlawanan berasosiasi dan direproduksi ke dalam alam sadar. Misalnya kita melihat orang tua maka akan teringat orang muda, melihat orang bertubuh besar teringat pula orang bertubuh kecil.

e. Hukum V: Hukum sebab akibat atau pertalian logis

Tanggapan-tanggapan yang mempunyai kaitan logis satu sama lain, timbul bersama-sama, berasosiasi dan direproduksikan ke dalam sadar. Misalnya, jika malam hari hujan lebat maka menimbulkan jalan licin. (Ahmadi :2009)

Jika dikaitkan dengan anak usia dini dalam buku kurikulum 2013, mengasosiasi (Associating): proses asosiasi merupakan proses lebih lanjut dimana anak ulai menghubungkan pengetahuan yang sudah dimilikinya dengan pengetahuan baru yang didaptakannya atau yang ada disekitarnya. Contoh anak belajar tentang segitiga melalui potongan kertas yang disiapkan guru. Guru mengajak anak untuk menemukan benda-benda yang ada disekitar yang berbentuk segitiga. Disini guru sudah mengasosiasikan atau menghubungkan pengetahuan baru tentang segitiga dengan benda-benda yang ada di lingkungan sekitarnya.

Proses asosiasi penting bagi anak utuk membangun pemahaman baru tentang dunia disekelilingnya. Piaget bahwa anak membentuk schemata baru tanpa membuang yang sudah ada tetapi memperbaiki dan menguatkan yang sebelumnya. Proses asosiasi dapat terlihat saat anak mampu:

1. Menyebutkan persamaan: itu sama dengan

2. Menyebutkan perbedaan: kalau ini...... tapi itu ......

3. Mengelompokkan: yang ini temannya iniMembandingkan: daunku lebih besar dari daun kamu 
Tentu saja kemampuan diatas sangat tergantung pada kemampuan yang dimiliki anak dan usia anak. Selain itu Buzan (2002) mengatakan bahwa perlu dirancang suatu bentuk gambar yang dapat menciptakan asosiasi dalam bentuk angka agar mudah diingat. Gambar aosiatif yang dibentuk akan lebih bertahan lama jika dihasilkan oleh sesorang tersebut. Buzan memberikan cara untuk memantapkan konsep tentang angka dengan menggunakan gambar benda yang mirip dengan bilangan yang dikenalkan atau memberikan cara untuk memantapkan konsep tentang huruf dengan menggunakan benda yang mirip pengucapan dan simbol hurufnya.

\section{Keaksaraan}

Aksara adalah sebuah sistem penulisan suatu bahasa dengan menggunakan tanda-tanda simbol, sebuah alfabet, huruf (Hidayat, 2009). Keaksaraan adalah keterampilan dasar seperti membaca, menulis dan berhitung (UNESCO, 2005:23 ). UNESCO mendefinisikan kemampuan keaksaraan atau melek aksara sebagai kemampuan seseorang untuk membaca dan menulis kalimat sederhana yang diperlukan dalam kehidupan sehari-hari (Bawani, 2014:61 ). Hal ini senada dengan Dappennas (2008) menyatakan Keaksaraan adalah hal yang berkaitan dengan menulis dan membaca (Deppennas, 2008).Keaksaraan adalah pembaca dan tanggapan amat menyadari bahwa menulis dan membaca berbeda dengan komunikasi lisan (Ong 2013). Sedangkan Kamisa (1997) menyatakan bahwa kata dasar keaksaraan adalah aksara yaitu sitem tanda-tanda grafis yang dipakai manusia untuk berkomunikasi dan sedikit banyaknya mewakili ujaran jenis sistem tanda grafis tertentu, misal aksara pallawa, aksara inka, huruf.

\section{Pembelajaran Keaksaraan}

Anak usia dini akan mengembangkan pengetahuan dan keterampilan keaksaraan melalui hubungan terus menerus dengan buku, bahasa, pengalaman motorik kasar dan halus. Keaksaraan bukan apa yang diajarkan dalam sebuah pelajaran, ini sesuatu yang wajar dalam pengalaman main sehari-hari. Huruf pertama yang anak kenal adalah huruf-huruf dari nama mereka sendiri. Kata pertama yang anak tulis adalah nama pertamanya (Yusro, 2013). Berdasarkan perkembangan keaksaraan menurut Peraturan Menteri Pendidikan dan 
Kebudayaan Republik Indonesia nomor 146 ahun 2014 tentang Kurikulum 2013 Pendidikan anak usia 5-6 tahun sebagai berikut :

1. Menunjukkan bentuk-bentuk simbol (pra penulis).

2. Membuat gambar dengan beberapa coretan/tulisan yang sudah berbentuk huruf/kata.

3. Menulis huruf-huruf dari namanya sendiri.

4. Menyebutkan angka bila diperlihatkan lambang bilangannya.

5. Menyebutkan jumlah benda dengan cara menghitung.

Adapun lingkup perkembangan keaksaraan menurut Peraturan Menteri Pendidikan dan Kebudayaan Republik Indonesia nomor 137 tahun 2014 tentang standar nasional pendidikan anak usia dini untuk anak usia 5-6 tahun sebagai berikut :

1. Menyebutkan simbol-simbol huruf yang dikenal.

2. Mengenal suara huruf awal dari nama benda-benda yang ada disekitarnya.

3. Menyebutkan kelompok gambar yang memiliki bunyi / huruf awal yang sama.

4. Memahami hubungan antara bunyi dan bentuk huruf.

5. Membaca nama sendiri.

6. Menuliskan nama sendiri.

7. Memahami arti kata dalam cerita 


\section{METODE PENELITIAN}

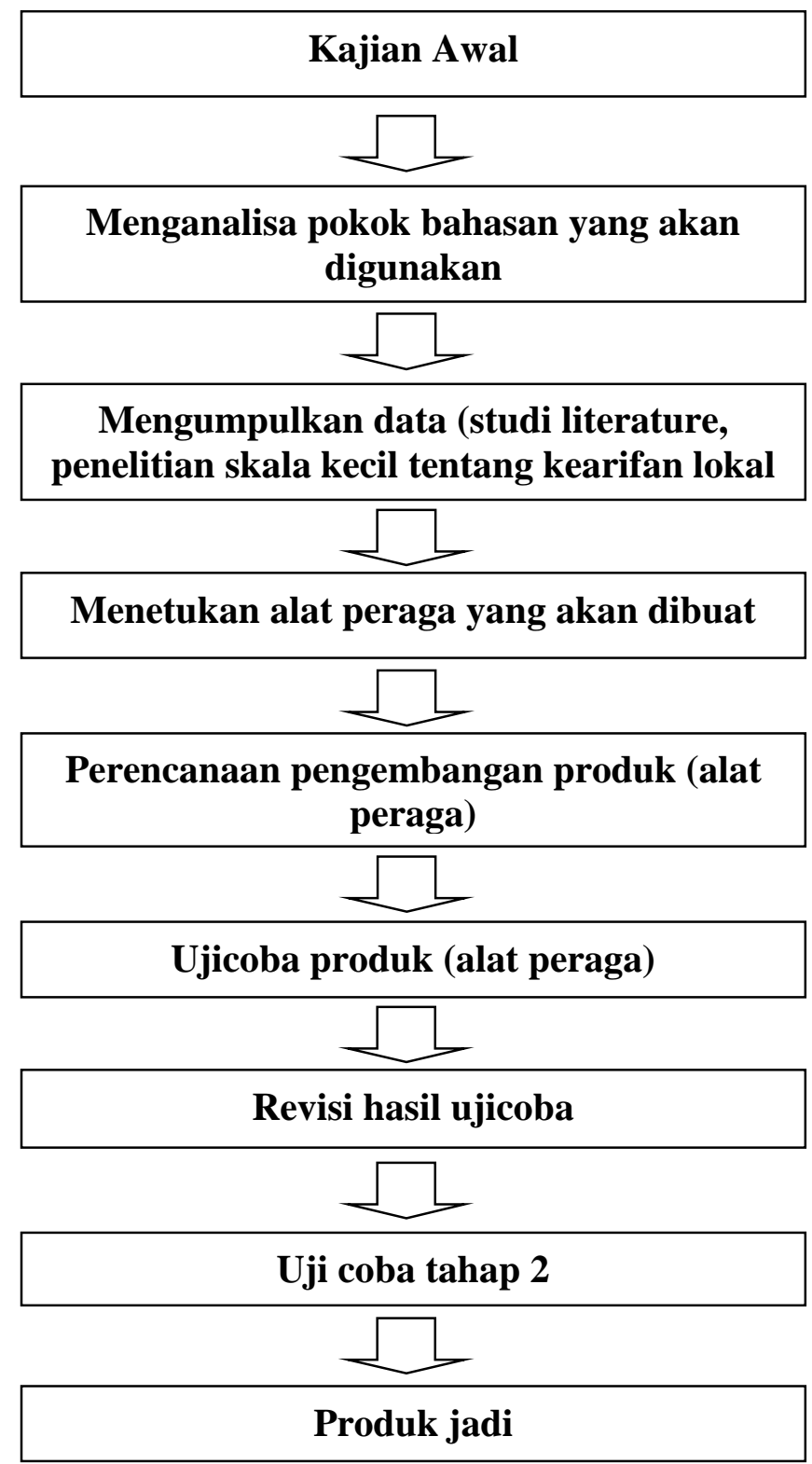

Adapun tempat penelitian akan dilaksanakan di 5 Lembaga Taman KanakKanak (TK) yang berada pada Gugus Bunga Matahari Palangkaraya. Adapun TK yang digunakan adalah :

1. TK Stella Sophie

2. TK Darussalam

3. TK Gemilang

4. TK Kristen Rajawali Sakti 


\section{TK Padehen}

Waktu Penelitian Penelitian ini dilaksanakan mulai tahap persiapan hingga pelaksanaan pada pengembangan berupa alat peraga keaksaraan dimulai semester ganjil Tahun Ajaran 2019/2020. Sasaran pada penelitian ini adalah anak TK dan guru di Lembaga Taman kanak kanak (TK) yang masuk dalam Gugus 11 Bunga Matahari Palangkaraya.

Pendekatan dan metode penelitian R \& D yang berpedoman pada Borg and Gall (Sukmadinata, 2008), dengan Produk yang dihasilkan yaitu berupa alat peraga keaksaraan bagi anak TK. Adapun Teknik pengumpulan data penelitian dilakukan dengan wawancara (tanya jawab) dan dokumentasi, sedangkan teknik analisis datanya menggunakan deskriptif kuantitatif.

Adapun indikator capaian penelitian ini adalah menurut Peraturan Menteri Pendidikan dan Kebudayaan Republik Indonesia nomor 146 ahun 2014 tentang Kurikulum 2013 Pendidikan anak usia 5-6 tahun (tentang perkembangan keaksaraan) sebagai berikut :

1. Menunjukkan bentuk-bentuk simbol (pra penulis).

2. Menyebutkan angka bila diperlihatkan lambang bilangannya.

\section{HASIL DAN PEMBAHASAN}

Hasil penelitian ini adalah menghasilkan alat peraga keaksaraan. Pengembangan alat peraga ini mengadaptasi metode Research and Development (R\&D) milik Borg dan Gall (Sugiyono, 2013), berikut akan diuraiakan hasil penelitian :

\section{Potensi dan Masalah}

Potensi kekayaan alam dan kebudayaan di Kalimantan Tengah sangat luar biasa, berbagai tumbuhan dan pernak pernik kebudayaan yang menjadi trendmark/kekhasan masyarakatnya sangat beragam dan menarik. Potensi kekayaan alam dan kebudayaan ini dapat di gunakan untuk mengembangkan alat peraga pembelajaran. Pada Pendidikan anak usia dini, alat peraga pembelajaran sangat penting untuk digunakan karena anak usia dini akan lebih mudah menyerap materi pembelajaran apabila dijelaskan dengan sesuatu yang dapat diamati secara langsung (kongkret).

Alat peraga pembelajaran yang memanfaatkan bahan bahan yang berasal dari potensi alam dan kebudayaan Kalimantan tengah secara khusus jarang ditemui, padahal 
potensi alam dan kebudayaan ini dapat dikelola untuk menciptakan alat peraga pembelajaran yang menarik untuk anak usia dini. Oleh karena itu penelitian ini akan membuat alat peraga keaksaraan berdasarkan potensi alam dan kebudayaan yang ada di Kalimantan Tengah.

\section{Mengumpulkan Informasi}

Peneliti mengumpulkan informasi yang berkaitan dengan potensi alam dan budaya yang ada di Kalimantan tengah sebagai bahan untuk merencanakan produk alat peraga keaksaraan. Peneliti mengumpulkan informasi yang diperlukan baik dari mencari di internet, pergi ke pasar tradisional untuk melihat potensi alam yang dijual di sana, dan pergi ke museum atau pun taman taman di ada di Kota Palangkaraya untuk melihat peralatan atau simbol simbol budaya Kalimantan Tengah yang dapat digunakan merencanakan desain awal produk alat peraga keaksaraan.

\section{Desain Produk}

Tahap awal yang dilakukan peneliti adalah melakukan kajian awal tentang pentingnya pengembangan media pembelajaran bagi anak usia dini, peneliti melakukan analisa terhadap topik pokok bahasan yang diangkat pada penelitian ini, tentang pentingnya melakukan inovasi media pembelajaran bagi pengembangan keaksaraan anak usia dini. Kemampuan keaksaraan ini diajarkan di Taman kanak-kanak, namun pada tingkat yang sangat dasar yaitu seperti mampu menyebut simbol angka yang dikenal ( 1 disebut angka 1, dst), kemampuan anak mengenal simbol angka ini akan lebih mudah apabila dibantu dengan menggunakan gambar asosiatif, yang mana gambar asosiatif ini dapat membantu anak mengingat simbol angka yang diajarkan kepadanya. Berdasarkan hal tersebut kemudian peneliti menentukan alat peraga yang akan dibuat.

Tahap selanjutnya adalah peneliti merencanakan pengembangan produk dalam bentuk alat peraga pembelajaran keaksaraan yang direncanakan dalam bentuk kartu angka dengan disertai gambar asosiatif. Gambar asosiatif yang menjadi padanan untuk simbol angka ini peneliti ambil dari benda atau jenis bahan makanan yang menjadi merupakan ciri khas/kearifan lokal kebudayaan Dayak Kalimantan Tengah. Peneliti kemudian melakukan observasi di museum, membaca literatur bahkan observasi ke pasar pasar tradisional untuk mencari benda atau bahan makanan lokal yang dapat 
dijadikan gambar asosiatif untuk simbol angka ini. Setelah peneliti menemukan beberapa benda dan juga beberapa jenis makanan yang dirasa sesuai dengan bentuk simbol angka yang dicari, peneliti kemudian mencoba mendesain gambar asosiatif dari benda dan bahan makanan yang telah memberikan validasi pada desain produk penelitian ini adalah dosen mata kuliah didapat untuk dicocokan dengan simbol angka $1-10$.

\section{Validasi Desain}

Validasi produk (alat peraga keaksaraan) dilakukan oleh tenaga ahli yang sudah berpengalaman untuk menilai produk yang telah dirancang. Tenaga ahli yang media dan sumber belajar (Ibu Ignatia Imelda Fitriani, M.Si), tenaga ahli ini merupakan salah satu tenaga pengajar di PG PAUD UPR, yang dianggap mempunyai keahlian menilai produk yang dibuat karena mengajar mata kuliah pembuatan media pembelajaran dalam pengembangan kegiatan belajar mengajar bagi anak usia dini khususnya di Taman Kanak kanak.

\section{Perbaikan Desain}

Setelah desain produk di validasi oleh tenaga ahli maka diketahui kelemahan dari produk penelitian ini (alat peraga keaksaraan), yang selanjutnya dapat dicoba untuk dikurangi dengan cara memperbaiki desain produk yang sudah dibuat.

\section{Uji Coba Produk}

Uji coba produk (alat peraga keaksaraan) dilakukan pada lingkup terbatas terlebih dahulu yaitu dilakukan pada salah satu TK (TK Stella Sophie Palangkaraya) yang ada di Gugus 11 Bunga Matahari dengan menggunakan 2 produk yang telah di desain sebelumnya yang menjadi prototipe produk penelitian ini. Tujuan dalam pengujian produk ini adalah untuk mendapatkan informasi apakah alat peraga keaksaraan ini dapat membantu anak usia dini melakukan penyimbolan terhadap aksara (huruf dan angka) yang diajarkan pada anak. Uji coba produk ini dilakukan dengan melakukan pengajaran pada anak dengan menggukan kartu angka yang dilengkapi dengan gambar asosiatif. Kemudian anak diajak bertanya jawab dengan melihat kartu angka ini dengan melihat dan membandingkan gambar asosiatif yang melengkapi 
gambar pada kartu angka yang ada. Kemudian peneliti menanyakan (mewanwancarai) kepada anak apakah gambar asosiatif yang tersedia mirip dengan simbol aksaranya (angka ). Setelah mewanwancarai anak diketahui berapa jumlah subjek penelitian yang menyatakan setuju (mirip) atau tidak setuju (tidak mirip) bahwa gambar asosiatif sesuai dengan simbol angkanya, dan kemudia hasil data yang ada akan dikelolal dengan rumus prosentase $(\mathrm{P}=\mathrm{F} / \mathrm{N} \times 100 \%)$. Dan berikut hasil pengumpulan datanya :

\begin{tabular}{|c|c|c|c|c|}
\hline $\begin{array}{l}\text { SIMBOL } \\
\text { ANGKA }\end{array}$ & GAMBAR ASOSIATIF & $\begin{array}{c}\text { KET. } \\
\text { GAMBAR }\end{array}$ & $\begin{array}{r}\text { RES } \\
\text { PON } \\
\text { SUB } \\
\text { JEK } \\
\text { N }=18\end{array}$ & $\begin{array}{l}\text { PRO } \\
\text { SEN } \\
\text { TASE }\end{array}$ \\
\hline $\mathbf{1}$ & & $\begin{array}{l}\text { Mandau adalah } \\
\text { senjata tajam sejenis } \\
\text { parang berasal dari } \\
\text { kebudayaan Dayak di } \\
\text { Kalimantan. Mandau } \\
\text { termasuk salah satu } \\
\text { senjata tradisonal. }\end{array}$ & 18 & $100 \%$ \\
\hline 2 & & $\begin{array}{l}\text { Enggang atau disebut } \\
\text { dengan burung adalah } \\
\text { Tinggang adalah salah } \\
\text { satu burung langka } \\
\text { yang di lindungi di } \\
\text { Indonesia. Binatang } \\
\text { yang lebih dikenal } \\
\text { dengan rangkong ini } \\
\text { konon di sakralkan } \\
\text { oleh suku Dayak. }\end{array}$ & 18 & $100 \%$ \\
\hline
\end{tabular}




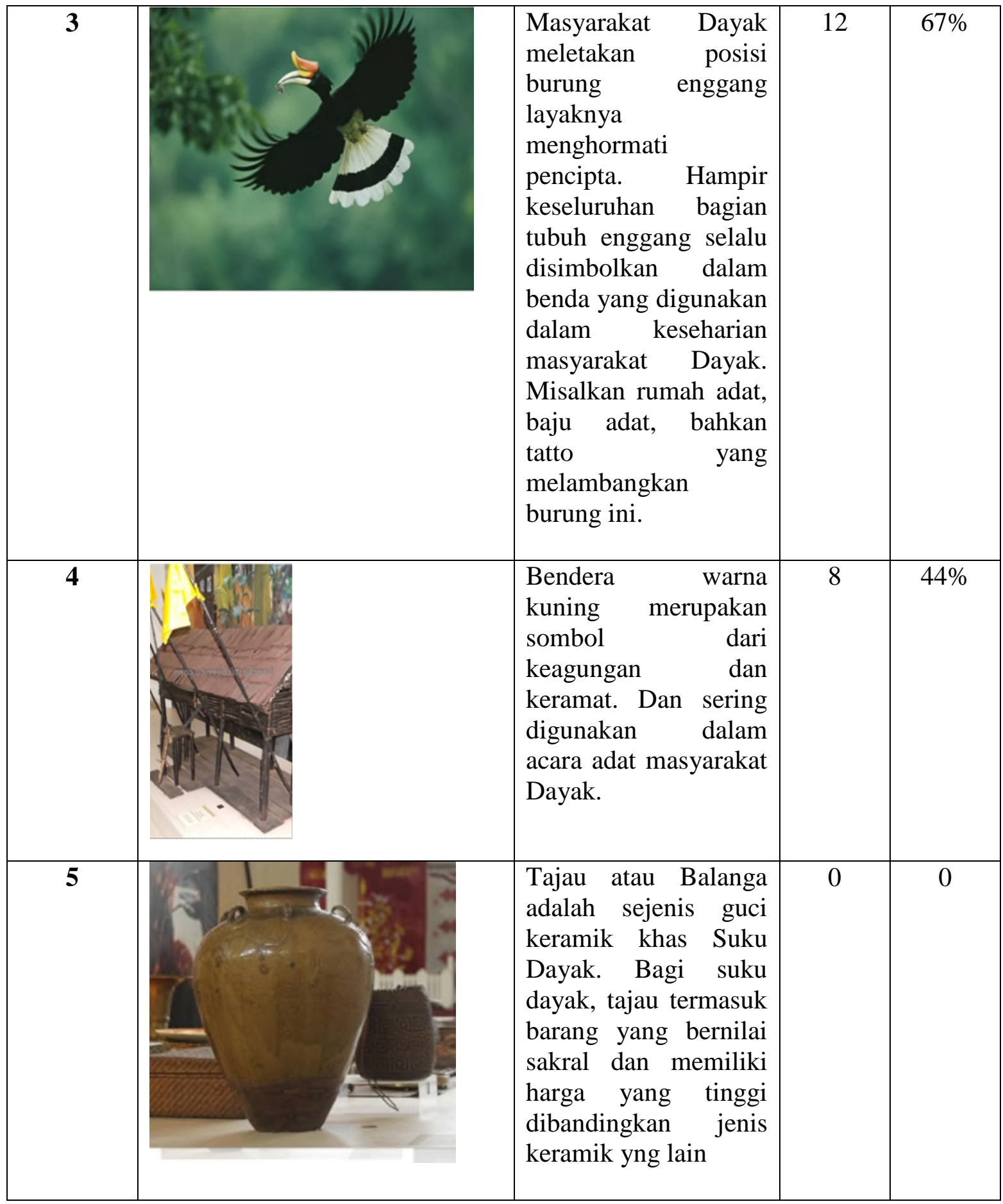




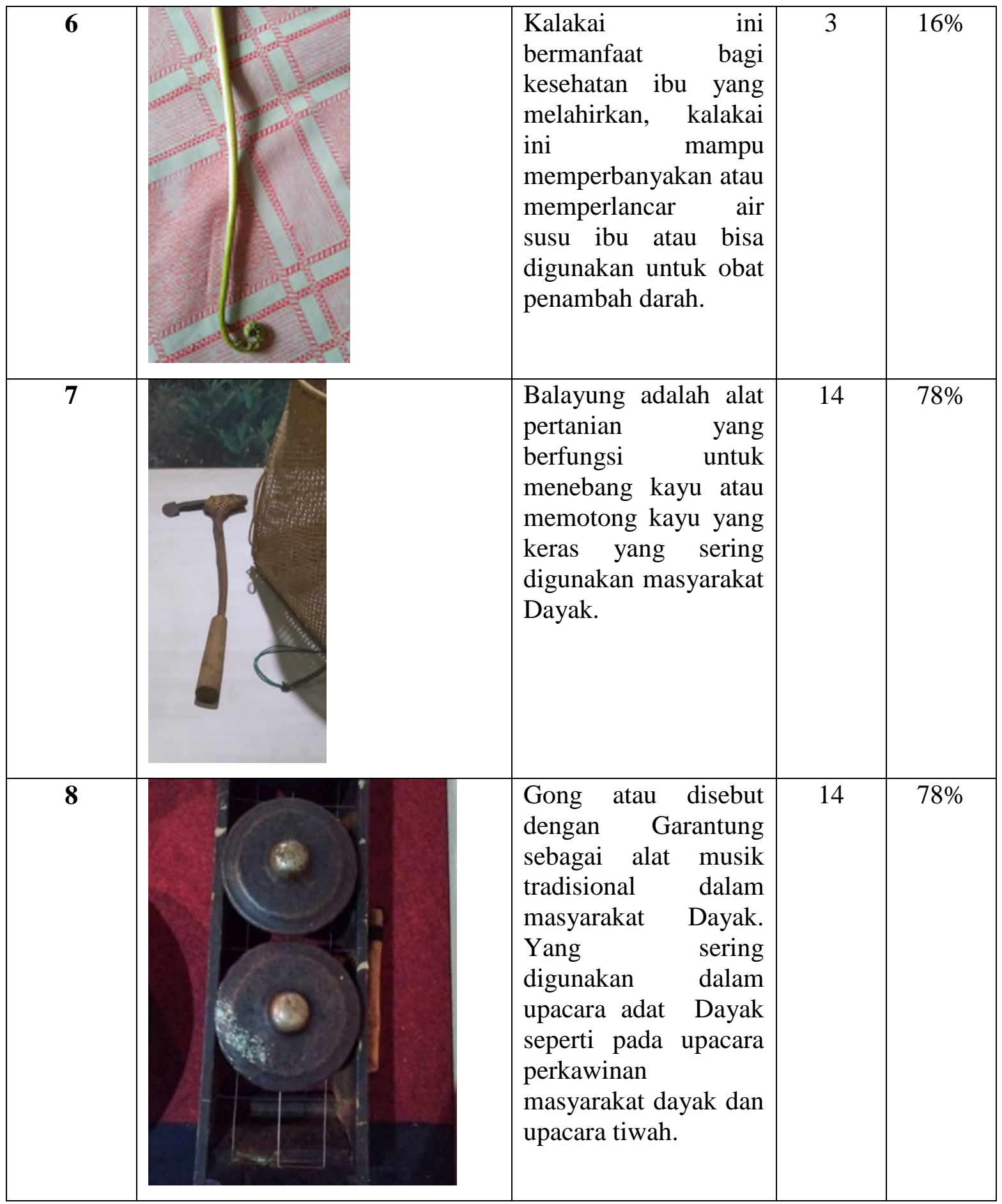




\begin{tabular}{|l|l|l|l|l|}
\hline 9 & $\begin{array}{l}\text { Kalakai ini } \\
\text { bermanfaat bagi } \\
\text { kesehatan ibu yang } \\
\text { melahirkan, kalakai } \\
\text { ini mampu } \\
\text { memperbanyakan atau } \\
\text { memperlancar air } \\
\text { susu ibu atau bisa } \\
\text { digunakan untuk obat } \\
\text { penambah darah. }\end{array}$ & 22\% \\
\hline 10 & $\begin{array}{l}\text { 1. Mandau adalah } \\
\text { senjata tajam sejenis } \\
\text { parang berasal dari } \\
\text { kebudayaan Dayak di } \\
\text { Kalimantan. Mandau } \\
\text { termasuk salah satu } \\
\text { senjata tradisonal. } \\
\text { 2. Gong atau disebut } \\
\text { dengan Garantung } \\
\text { sebagai alat musik } \\
\text { tradisional dalam } \\
\text { masyarakat Dayak. } \\
\text { Yang sering } \\
\text { digunakan dalam } \\
\text { upacara adat Dayak } \\
\text { seperti pada upacara } \\
\text { perkawinan } \\
\text { masyarakat dayak dan } \\
\text { upacara tiwah. }\end{array}$ & $78 \%$ \\
\end{tabular}

Dari data di atas diketahui bahwa untuk alat peraga keaksaraan untuk gambar asosiatif untuk merujuk angka 3, 4, 5, 6, 9 dibawah 50\%, artinya banyak anak yang menyatakan bahwa gambar asosiatif yang menyimbolkan angka 3, 4, 5, 6 dan 9 tidak atau kurang tampak mirip dengan simbol angkanya. Angka $5(0 \%)$ dengan gambar asosiatif Balanga, anak melihat tidak ada kemiripan antara simbol angka dengan gambar asosiatifnya, sedangkan angka $3(67 \%), 4(44 \%), 6(16 \%)$ dan $9(22 \%)$ hanya ada sedikit anak yang mengatakan simbol angka dengan gambar asosiatifnya mirip.

Setelah dilakukan uji produk secara terbatas dan diketahui hasilnya maka kemudian peneliti melakukan revisi produk dengan memperhatikan hasil data yang telah diperoleh di atas, 


\section{Revisi Produk}

Pengujian produk alat peraga keaksaraan tahap awal telah dilakukan dan diketahui bahwa masih ada gambar gambar asosiatif yang pada tahap desain produk dianggap dapat menjadi gambar asosiatif dari simbol angka namun ditemukan masih ada yang kurang tepat gambar asosiatifnya untuk mewakili simbol angkanya. Oleh karena itu pada tahap ini peneliti mencoba untuk merevisi produk awal yang telah dibuat. Adapun revisi produk yang dibuat adalah dengan mencari benda / produk lain yang lebih beragam dari kebudayaan daerah Kalimantan Tengah yang dapat dijadikan gambar asosiatif dari simbol angka . Berikut pilihan benda/produk yang coba dicari lagi guna memperbaiki gambar asosiatif yang telah diuji coba sebelumnya sehingga selanjutnya akan ditemukan benda /produk yang lebih mendekati kemiripan dengan simbol angka dan kemudian akan dibuat menjadi gambar asosiatifnya.

Berdasarkan hasil penelitian di atas diketahui bahwa ada beberapa gambar dari benda atau produk hasil pangan yang ada di Kalimantan Tengah ini dapat digunakan sebagai gamabr asosiatif dari simbol angka. Penggunaan gambar asosiatif ini bertujuan agar anak mengalami proses asosiatif, yang mana anak mempunyai kemampuan untuk menghubungkan pengetahuan baru yang didapatkannya dengan pengetahuan yang dimilikinya. Di sekolah anak sudah belajar tentang simbol angka 1-10 namun anak masih suka lupa atau tertukar dalam megingat simbol angka 1-10 dengan adanya gambar asosiatif ini guru dapat menghubungkan pengetahuan tentang simbol angka yang pernah dipelajarinya dengan gambar asosiatif yang diajarkan padanya, misal angka 1 yang bentuknya seperti Singkah Uwei, angka 2 yang bentuknya seperti Burung tinggang, angka 3 yang bentuknya seperti burung tingang terbang, angka 4 yang bentuknya seperti Bendera keramat Dayak, angka 5 yang bentuknya seperti Burung Tinggang duduk., angka 6 bentuknya seperti kelakai , angka 7 bentuknya seperti Waliung, angka 8 bentunya seperti Gelang bawok, angka 9 bentuknya seperti bajai dan angka 10 bentuknya seperti singkah uwei dan terong asam.

Buzan (2002) menyatakan bahwa perlu dirancang suatu bentuk gambar yang dapat menciptakan asosiasi dalam bentuk angka agar mudah diingat . Gambar asosiaatif ini akan lebih memudahkan anak mengingat simbol angka yang dipelajarinya. Proses asosiatif ini penting bagi anak untuk membangun pemahaman baru tentang dunia 
disekelilingnya dan akan menguatkan dan memperbaiki pengetahuan yang sudah dimiliki anak sebelumnya.

\section{KESIMPULAN}

\section{Kesimpulan}

Berdasarkan uraian diatas dapat disimpulkan bahwa hasil penelitian ini dapat dihasilkan alat peraga yang keaksaraan yang berbasis kemampuan simbolik anak yang ada di Gugus 11 Bunga Matahari. Produk dan benda lokal yang menjadi kekhasan masyarakat Dayak Kalimanatan Tengah digunakan sebagai gambar asosiatif yang menyimbolkan angka 1-10, dan produk hasil akhir dari penelitian ini adalah alat peraga pembelajaran yang berupa kartu gambar asosiatif angka yang dilengkapi dengan gambar asosiatif dari simbol angka 1-10 .

\section{Saran}

a) Alat peraga ini dapat digunakan guna mengembangkan kemampuan keaksaraan anak usia dini, dan alat peraga ini dapat juga digunakan sebagai media dalam memperkenalkan produk atau benda lokal yang menjadi kekhasan masyarakat Dayak di Kalimantan Tengah

b) Alat peraga serupa dapat dikembangkan oleh peneliti selanjutnya guna menciptakan alat peraga pembelajaran yang akan mempermudah anak usia dini dalam belajar, misalnya membuat kartu gambar asosiatif untuk membantu anak mengingat bentuk geometri. 


\section{DAFTAR PUSTAKA}

Bawani, Imam (2014). Pengelolaan Program Keaksaraan Fungsional Untuk Memberantas Buta Aksara, Surabaya:Jurnal Kependidikan Islam, Volume 4, Nomor 1, Tahun 2014.

Buzan, Tony. (2002). Use Your Perfect Memory: Teknik Optimalisasi Daya Ingat.Yogyakarta: Ikon Teralita.

Departemen Pendidikan Nasional (2008) Kamus Besar Bahasa Indonesia Pusat Bahasa Edisi Keempat, Jakarta: PT Gramedia Pustaka Utama.

Fitriyanti. 2015. Meningkatkan kemampuan Mengenal Angka 1-10 Dengan Media Asosiatif Di Kelompok B TK Budi Rahayu. Jurnal Pendidikan Guru PAUD Edisi 6 Tahun ke-4

Kamisa (2013) Kamus Besar Bahasa Indonesia, Surabaya: Cahaya Agensi

Mariyah, Aprinastuti, C. \& Anggadewi, B.E.T. 2017. PROSIDING TEMU ILMIAH X IKATAN PSIKOLOGI PERKEMBANGAN INDONESIA Peran Psikologi Perkembangan dalam Penumbuhan Humanitas pada Era Digital 22-24 Agustus 2017, Hotel Grasia, Semarang 240 ISBN: 978-602-1145-49-4 Pengembangan alat peraga untuk meningkatkan kemampuan belajar matematika pada anak dengan ADHD

Mutiah, Diana. (2010). Psikologi Bermain Anak Usia Dini. Jakarta: Penerbit Kencana

Nabila, Laila. 2018. Pengembangan Alat Peraga Berbahan Bekas Pakai Sebagai Wujud Peduli Lingkungan Pada Peserta Didik SMPN/MTsN Kabupaten Pesisir Barat. Skripsi. Lampung : UIN Raden Intan Lampung

Ong, J. Walter (2013) Kalisanan dan Keaksaraan, Yogyakarta: Gading Publishing.

Sustiari, Lilik (2014). Peningkatan Kemampuan Keaksaraan Pada Anak Melalui Metode Teka-Teki Bergambar Di RA Muslimat Nu Pasuruhan 1 Metroyudan Magelang. Yogyakarta: Universitas Islam Negeri Sunan Kalijaga.

Peraturan Menteri Pendidikan Dan Kebudayaan Republik Indonesia No 146 Tahun 2014Tentang Standard Nasional Pendidikan Anak Usia Dini

Runtukahu, Tombokan Dan Selpius Kandou. (2014). Pembelajaran Matematika Dasar Bagi Anak Berkesulitan Belajar. Yogyakarta: Aruzz Media

Sriningsih, nining (2008). Pembelajaran Matematika Terpadu Untuk Anak Usia Dini. Bandung: Pustaka Sebelas

UNESCO (2005). Prakarsa Keaksaraan Untuk Pemberdayaan Masyarakat; Jakarta: UNESCO.

Yusro, Sulastri (2013). Pembelajaran Keaksaraan Untuk Anak Usia Dini, Jurnal Pendidikan Anak Pendidikan Anak, Volume II, Edisi 2, Desember 2013; PGTK/RA STPI Bina Insan Mulia Yogyakarta 